\title{
Potential role of sulfide and ammonia as confounding factors in elutriate toxicity bioassays with early life stages of sea urchins and bivalves
}

\author{
Chiara Losso $^{\mathrm{a}}$, Alessandra Arizzi Novelli, ${ }^{\mathrm{a}, *}$, Marco Picone ${ }^{\mathrm{a}}$, Davide Marchetto ${ }^{\mathrm{a}}$, \\ Claudio Pantani ${ }^{\mathrm{b}}$, Pier Francesco Ghetti ${ }^{\mathrm{a}}$, Annamaria Volpi Ghirardini ${ }^{\mathrm{a}}$ \\ ${ }^{a}$ Department of Environmental Sciences, University of Venice, Campo della celestia 2737/b, I-30122 Venice, Italy \\ ${ }^{\mathrm{b}}$ Department of Environmental Sciences, University of L'Aquila, Via Vetoio, 20, I-67010 Coppito, L'Aquila, Italy
}

Received 30 May 2005; received in revised form 25 October 2005; accepted 19 December 2005

Available online 7 February 2006

\begin{abstract}
This work reports some considerations on the possible contribution of sulfide and ammonia to the toxicity of elutriate samples of sediments from the Venice lagoon, tested with a battery of bioassays using early life stages of the sea urchin Paracentrotus lividus and the oyster Crassostrea gigas. A comparison of ammonia or sulfide concentration in the test matrix, matrix toxicity, and the sensitivity limit of bioassays for ammonia or sulfide were used in evaluating toxicity data. Results highlighted that sperm cell and embryo toxicity of elutriates were not affected by sulfides. Neither was any direct relationship shown between elutriate toxicity and ammonia concentration. Most elutriates had ammonia concentrations below the sensitivity limit of acute test methods, while the more sensitive subchronic toxicity tests were affected by ammonia interference in some samples.
\end{abstract}

(C) 2006 Elsevier Inc. All rights reserved.

Keywords: Paracentrotus lividus; Crassostrea gigas; Ammonia; Sulfides

\section{Introduction}

In a monitoring program, a first question could be, "Which toxicity test is applicable to this environment?" followed by, "How reliable will the data be?" Evaluation of the applicability of toxicity bioassays to an environment involves different steps, with progressive iterative evaluations of methods and recalibration of procedures that could slightly modify operative protocols. A central phase of this validation process is evaluation of the test applicability to the environmental matrices and of the test's discriminatory power, focusing on identification of possible chemical or physical interference. Some important variables in test matrices (elutriates and, particularly, pore waters), called "confounding factors," occur naturally and interfere with the biological effects of micropollutants, frequently giving rise to a "false positive" (Giesy and Hoke, 1990; Matthiessen et al., 1998; Morin and Morse,

\footnotetext{
${ }^{*}$ Corresponding author. Fax: + 390415281494 .

E-mail address: arizzi@unive.it (A.A. Novelli).
}

1999; Postma et al., 2002; Thursby et al., 1997) and labelling a sample as toxic that is not so in reality.

Recognized confounding factors include sediment texture (De Witt et al., 1988) and matrix parameters such as temperature, salinity, and dissolved oxygen, ammonia, and sulfide concentrations (Lapota et al., 2000; Postma et al., 2002). Furthermore, the method for extracting and diluting test matrices may influence sample hypoxic condition and natural toxicant concentrations and, consequently, the final toxicity (Beiras, 2002).

In recent years, we have been studying the applicability to a transitional environment of bioassays using the early life stages of the sea urchin (Paracentrotus lividus) and oyster (Crassostrea gigas), with the Venice lagoon as a case study (Arizzi Novelli et al., 2003a; Volpi Ghirardini et al., 2003).

In these toxicity bioassays, the most important confounding factors are the presence of ammonia and sulfide; during the test, temperature and salinity are kept within the optimal range for organisms and dissolved oxygen has values over $80 \%$ of saturation. Many authors have 
reported recently that the toxicity of elutriates and pore waters from marine and coastal environments was influenced by ammonia when routine tests were used (Ankley et al., 1991; Carr et al., 1996a,b; Postma et al., 2002; Whiteman et al., 1996). No normal ranges of ammonia and sulfide in elutriates and pore waters are specified in the literature. For surface waters, the US EPA proposed a limit of $2 \mu \mathrm{g} / \mathrm{L}$ for sulfide and $35 \mu \mathrm{g} / \mathrm{L}$ for ammonia as quality criteria (Wang and Chapman, 1999).

Moreover, the sensitivity of the test methods used in monitoring towards these substances is often not available. With sea urchin bioassays, for example, ammonia toxicity data are available for Arbacia punctulata (Carr et al., 1996a; Hooten and Carr, 1998) and Strongylocentrotus purpuratus (Bay et al., 1993; Greenstein et al., 1996), and sulfide data are available for S. purpuratus (Knezovich et al., 1996), but no information has been found for a test with the species $P$. lividus. For this reason our research group recently studied the sensitivity of sperm cell and embryo toxicity test with $P$. lividus toward ammonia and sulfide (Arizzi Novelli et al., 2003b; Losso et al., 2004a, b).

In transitional environments, such as the Venice lagoon, naturally rich in organic matter and often characterized by anoxic conditions in areas with low water turnover, concentrations of ammonia and sulfide can be defined ad hoc, according to the considerations recently proposed for estuaries (Chapman and Wang 2001).

In polluted environments, a high concentration of ammonia in sediments can be due mostly to human activities directly introducing ammonia into waters or increasing organic matter in sediments. In this case, ammonia is considered a pollutant and not a confounding factor. To the best of our knowledge, no studies on "background" concentrations of ammonia and sulfide in coastal and/or marine environments are available that make it possible to discriminate between anthropogenic and natural ammonia and/or sulfide.

What then can be done with environmental samples at high concentrations of ammonia and/or sulfide? International protocols recommend that concentrations of these substances in tested matrices not exceed the sensitivity limits of bioassays (American Society for Testing and Materials (ASTM), 1998). This means that most lagoon elutriates or pore waters cannot be tested if even a part of the ammonia concentration might be derived from human sources. We also have to consider that test matrices are diluted in several solutions in order to obtain EC50 (Effective Concentration 50) values, so this also means dilution of the ammonia and/or sulfide concentration. For this reason, the best solution may be to test the samples at high concentrations of ammonia and/or sulfide and then discuss the obtained toxicity data, taking into account all available information.

This work aims at the following:

- Continuing to evaluate the applicability of the test with sea urchins and oysters to the elutriates of the Venice lagoon; the discriminatory power of the test with $P$. lividus has already been evaluated (Losso et al., 2004b; Volpi Ghirardini et al., 2003).

- Acquiring new data on elutriate toxicity for the Venice lagoon using sea urchin and bivalves.

- Evaluating if toxicity data are affected by confounding factors, comparing ammonia and sulfide concentrations in the test matrix, test matrix toxicity, and the sensitivity limit of bioassays for ammonia and sulfide.

\section{Materials and methods}

\subsection{Sperm cell and embryo toxicity tests with P. lividus}

Adults of $P$. lividus were collected from a rocky breakwater in the northern Adriatic Sea, near the barrier island of Pellestrina $\left(45^{\circ} 18^{\prime} 50^{\prime \prime} \mathrm{N}\right.$; $12^{\circ} 19^{\prime} 24^{\prime \prime} \mathrm{E}$ ), on the seaward side of the Lagoon of Venice, Italy. Sea urchins were kept for up to one month in flowing seawater from the sampling site, maintained on macroalgae and molluscs, at a temperature of $18 \pm 1{ }^{\circ} \mathrm{C}$ and salinity of $35 \pm 1 \%$, with a natural photoperiod. Adult collection and culture procedures have previously been reported in detail (Volpi Ghirardini and Arizzi Novelli, 2001).

The sperm cell toxicity test was performed using the following procedure (Volpi Ghirardini and Arizzi Novelli, 2001). Sea urchins were induced to spawn by injecting $1 \mathrm{ml}$ of $0.5-1 \mathrm{M} \mathrm{KCl}$ solution. Pools were prepared of male and female gametes (minimum three males and three females). A volume of $0.1 \mathrm{ml}$ of adjusted suspension of $4 \times 10^{7}$ sperm was added to test solutions. After $60 \mathrm{~min}$ of exposure, $1 \mathrm{ml}$ of standardized egg suspension $\left(\right.$ at $18^{\circ} \mathrm{C}$ ) was added to test vessels, and a period of $20 \mathrm{~min}$ was allowed to pass. Samples for counting were preserved in $1 \mathrm{ml}$ of concentrated buffered formalin, and the fertilization percentage in each treatment was determined by counting 200 eggs.

The embryo toxicity, performed using the procedure reported in detail (Arizzi Novelli et al., 2002), consists of the same steps up to sperm and egg density determination; the gametes were then put together at a sperm:egg ratio of 10:1. A period of $20 \mathrm{~min}$ was allowed for fertilization. A volume of $1 \mathrm{ml}$ of fertilized egg suspension was added to $10-\mathrm{ml}$ aliquots of test solution and incubated in a dark room at $18^{\circ} \mathrm{C}$ for $72 \mathrm{~h}$. At the end of the experiment, samples for counting were preserved in $1 \mathrm{ml}$ of concentrated buffered formalin, and the percentage of plutei with normal development in each treatment was determined by observing 100 larvae.

Sterile capped polystyrene six-well microplates (Iwaki brand, Asahi Techno Glass Corporation, Tokyo, Japan) were used as test chambers for both toxicity tests. Dilution water (for test solutions and gametes) was artificial sea water reconstituted according to ASTM (1998) at a salinity of 34 ppt.

Acceptability of test results was fixed at (a) fertilization rate and percentage of normal plutei $\geqslant 70 \%$ in control tests; (b) EC50 using the reference toxicant (copper solutions prepared from copper nitrate standard solution for atomic absorption spectroscopy) falling within previously defined acceptability ranges for both tests (Arizzi Novelli et al., 2002; Volpi Ghirardini and Arizzi Novelli, 2001).

\subsection{Embryo toxicity test with C. gigas}

Conditioned adults of $C$. gigas were purchased from the Guernsey Sea Farm Limited hatchery (Guernsey, United Kingdom). The embryo toxicity test was performed according to the method proposed by His et al. (1997), based on the standard protocol of the U.S. Environmental Protection Agency (1995). Adults were induced to spawn by thermal stimulation (temperature cycles at 18 and $28^{\circ} \mathrm{C}$ ). Gametes of good quality derived from the best males and females were selected and filtered at $32 \mu \mathrm{m}$ (sperm) and $100 \mu \mathrm{m}$ (eggs) to remove impurities. Eggs $(1000 \mathrm{ml})$ were fertilized by injecting $10 \mathrm{ml}$ of sperm; fecundation was verified by 
microscopy. Egg density was determined by counting four subsamples of known volume. Fertilized eggs, added to test solutions in order to obtain a density of $60 \mathrm{eggs} / \mathrm{ml}$, were incubated for $24 \mathrm{~h}$ at $24^{\circ} \mathrm{C}$. At the end of the test, samples were fixed with buffered formalin and 100 larvae were counted, distinguishing between normal larvae (D-shaped) and abnormalities (malformed larvae and prelarval stages). Acceptability of test results was based on negative control for a percentage of normal D-shaped larvae $\geqslant 80 \%$ (His et al., 1999). Sterile capped polystyrene 24-well microplates (Iwaki brand, Asahi Techno Glass Corporation, Tokyo, Japan) were used as test chambers for the toxicity test. Dilution water (for test solutions and gametes) was artificial sea water reconstituted according to ASTM (1998) at a salinity of $34 \mathrm{ppt}$.

\subsection{Preparing, testing, and analyzing elutriates}

Elutriates were prepared from sediments from 12 sites in the Venice Lagoon with different types and levels of contamination. Sediment sampling and storage are reported in detail in Volpi Ghirardini et al. (2005). All sites were investigated at least twice (from 1998 to 2003) in late winter and late summer; samples were identified by letters for the sampling stations, followed by season $(\mathrm{w}=$ winter; $\mathrm{s}=$ summer) and year. Some samples had already been investigated with $P$. lividus (Losso et al., 2004b).

Elutriates were prepared according to the method reported in Volpi Ghirardini et al. (2003). Briefly, the elutriation steps were as follows: addition of artificial seawater (Ocean Fish, Prodac International, Cittadella, PD, Italy) to sediment samples at a sample dilution of $1: 4 w^{\prime} / v$ ( $w^{\prime}=$ sediment dry weight; $v=$ dilution water volume); stirring of the sediment-water mixture for $24 \mathrm{~h}$ at $230 \mathrm{rpm}$ at $4{ }^{\circ} \mathrm{C}$ using a Jar test (Model ISCO, Vittadini, Milan, Italy); settling of the mixture for $60 \mathrm{~min}$ at $4{ }^{\circ} \mathrm{C}$; centrifuging of the supernatant at $7700 \mathrm{~g}$ at $4{ }^{\circ} \mathrm{C}$ for $15 \mathrm{~min}$ using a refrigerated ultracentrifuge (Model L7-35, Beckmann, Milan, Italy); storing the supernatant, without filtering, in 100-ml PE containers, and then freezing it at $-18^{\circ} \mathrm{C}$ for later toxicological analyses. for total ammonia and sulfide analyses, $100 \mathrm{ml}$ of each elutriate sample was filtered through Whatman GF/F 0.7- $\mu$ m filters.

Elutriate toxicity was investigated using the above-quoted toxicity tests. Three experimental replicates were performed for each elutriate percentage $(6 \%, 12 \%, 25 \%, 50 \%, 75 \%, 100 \%)$ and for the negative control test.

Sulfide and total ammonia concentrations in elutriates were measured with a spectrophotometer (Model DR/2010, HACH, Loveland, CO) using the methylene blue method (USEPA SM 4500-S2 D) for sulfides and the salicylate method (Reardon et al., 1966) for total ammonia. Elutriate $\mathrm{pH}$ was measured using a pH meter (perpHecT LogR meter, Model 330, Orion, Beverly, MA).

\subsection{Toxicological data analysis}

Data are expressed as EC50 values based on the percentages of "nonfertilized" eggs (sperm cell toxicity test) and "abnormal larvae" (embryo toxicity test). EC50 values with 95\% confidence limits were calculated by Trimmed Spearman-Karber (Hamilton et al., 1978). The responses for each treatment ( $\%$ of fertilized eggs and $\%$ of abnormalities) were corrected for effects in control tests by applying Abbott's formula (Finney, 1971). The EC50 values for elutriates are reported as percentages of elutriates in artificial water.

\section{Results and discussion}

\section{1. $Q A / Q C$ for toxicity tests}

Tests with $P$. lividus showed good repeatability, evaluated using copper as a positive control: the sperm cell toxicity test had a mean EC50 \pm SD (standard deviation) of $55 \pm 8 \mu \mathrm{g} / \mathrm{L}(\mathrm{CV}$ (coefficient of variation) $=15 \%, n=25)$, which was within the EC50 acceptability range $(39-71 \mu \mathrm{g} / \mathrm{L})$
(Volpi Ghirardini and Arizzi Novelli, 2001); the embryo toxicity test highlighted a mean EC50 \pm SD of $68 \pm 9 \mu \mathrm{g} / \mathrm{L}$ $(\mathrm{CV}=13 \%, n=9)$, within the EC50 acceptability range (51-87 $\mathrm{g} / \mathrm{L})$ (Arizzi Novelli et al., 2002).

For the embryotoxicity test with oyster the scant number of experiments did not allow repeatability to be tested, even if the EC50 \pm confidence limit at $95 \%$ obtained comparable values $(12.3 \pm 0.7$ and $14.3 \pm 0.7 \mu \mathrm{g} / \mathrm{L})$.

\subsection{Elutriate samples}

The concentrations of ammonia and sulfide in elutriates, elutriate toxicity, and the toxicological parameters indicating method sensitivity towards sulfide and ammonia were taken into account in order to evaluate the possible contribution of sulfide and ammonia to the toxicity.

All elutriate samples showed $\mathrm{pH}$ values between 7.7 and 8.3 , in agreement with the toxicity test standard protocols.

Concerning toxicological parameters, the following data are available in the literature:

Total sulfide: $\mathrm{EC} 5=0.36 \mathrm{mg} / \mathrm{L}, \mathrm{EC} 50=1.20 \mathrm{mg} / \mathrm{L}$ for sperm cell test with $P$. lividus, NOEC (no observed effect concentration) $=0.10 \mathrm{mg} / \mathrm{L}, \mathrm{EC} 50=0.43 \mathrm{mg} / \mathrm{L}$ for embryotoxicity test with $P$. lividus (Losso et al., 2004a), $\mathrm{NOEC}=0.10 \mathrm{mg} / \mathrm{L}$ for embryotoxicity test with $C$. gigas (ASTM, 1998).

Total ammonia: $\mathrm{EC} 5=15.3 \mathrm{mg} / \mathrm{L}$ and $\mathrm{EC} 50=25.4 \mathrm{mg} / \mathrm{L}$ at $\mathrm{pH} 8.0$ for sperm cell test with $P$. lividus (which is less sensitive to ammonia), NOEC $=0.5 \mathrm{mg} / \mathrm{L}$, LOEC (lowest observed effect concentration $)=1 \mathrm{mg} / \mathrm{L}$ and $\mathrm{EC} 50=$ $4.2 \mathrm{mg} / \mathrm{L}$ at $\mathrm{pH} 8.0$ for embryotoxicity test with $P$. lividus (Arizzi Novelli et al., 2003b), NOEC $=4.7$ at $\mathrm{pH} 7.8-8.1$ for embryotoxicity test with C. gigas (ASTM, 1998).

Within this context, the EC5 and LOEC values could be considered equivalent, since they indicated the lowest concentration causing toxic effect.

In Fig. 1, the concentration of total sulfide for elutriate samples (abscissa) was related to the toxicity of the elutriates. For samples at low toxicity, the data are expressed as percentage of effect, i.e., the percentage of unfertilized eggs or anomalies in larval development in undiluted elutriate (ordinate in Figs. 1a-c). For samples at high toxicity, data are expressed in TU50 (Toxic Unit 50) values calculated taking into account elutriate dilutions (Figs. 1d,e). The data were also related to the concentration of total sulfide extrapolated for the dilution causing 50\% of effect, assuming that sulfide concentration decreases linearly at increasing elutriate dilution (Fig. 1f). In the graphs, the NOEC or EC5 values representing method sensitivity toward sulfide are evidenced by a black bar. For the sperm cell toxicity test with $P$. lividus, most samples showed low toxicity; only three samples of sediment from the industrial area had high acute toxicity. In both cases, Fig. 1 shows that sulfide cannot contribute to elutriate toxicity in the sperm cell toxicity test, since most elutriates had sulfide concentrations below the EC5 value. Sulfide concentrations were above EC5 values only for samples 
Sperm cell toxicity test with $P$. lividus
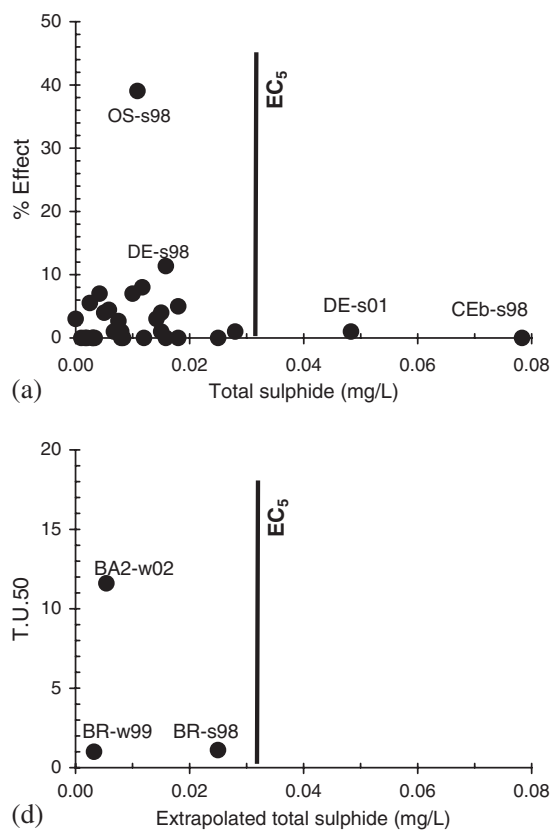

Embryotoxicity test with $P$. lividus
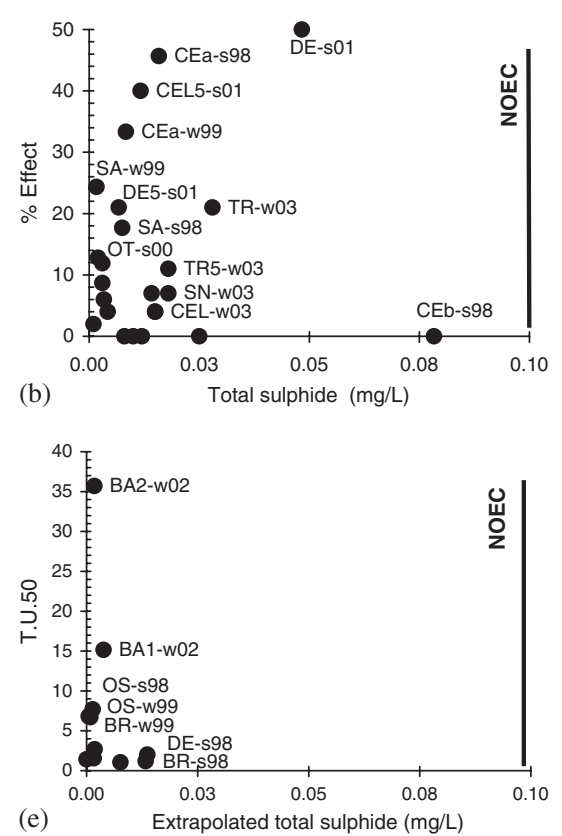

Embryotoxicity test with C. gigas
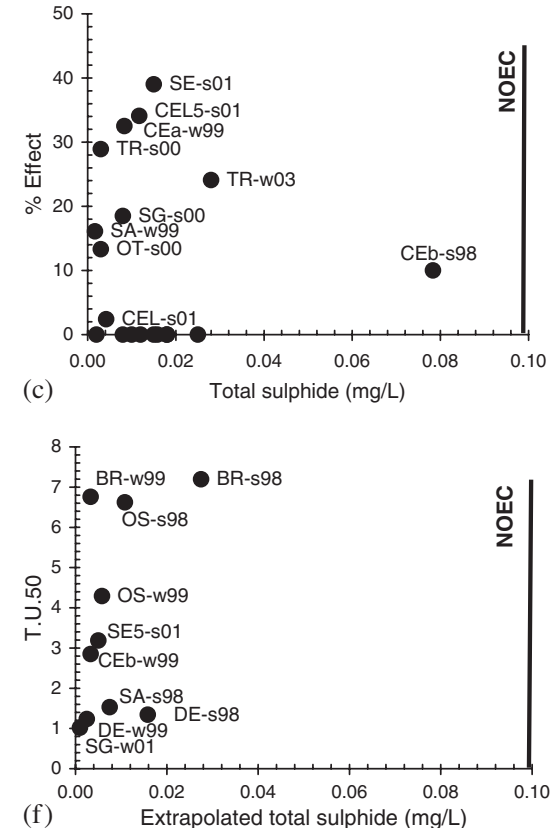

Fig. 1. Concentration of total sulfide in elutriates, related to elutriate toxicity (expressed as percentage of effect in samples with low toxicity (a, b, and c) and TU50 (d, e and f) in samples with high toxicity), tested with the sea urchin $P$. lividus and the oyster $C$. gigas. The black bar highlights sensitivity limit toward sulfide for each method (EC5 for sperm cell test and NOEC for embryotoxicity test). For samples with high toxicity, total sulfide concentrations were extrapolated for the dilution of samples causing $50 \%$ of effect.

DE-s01 (from estuarine site) and CEb-s98 (possible reference site), but elutriates did not have acute toxicity. For the embryotoxicity test with $P$. lividus and $C$. gigas sulfide did not contribute to subchronic toxicity for samples at either low or high toxicity. These results regarded elutriates obtained after $24 \mathrm{~h}$ sediment-water oxidation, which promotes the elimination of the major part of sulfides. For other environment matrices, such as pore waters collected with an in situ sampler in the Lagoon of Venice, the influence of sulfide concentrations on toxicity effects in real anoxic samples may be relevant (Losso et al., 2004a).

Fig. 2 reports considerations on the possible contribution of ammonia to the toxicity. For the sperm cell toxicity test with $P$. lividus, the toxicity of most samples was not influenced by ammonia, with the exception of BR-s98, BRw99, and OS-w99, which had ammonia concentrations exceeding the EC5 value, and OS-s98 and BA1-w02 (not reported in the graph because out of order, with a total ammonia concentration of $160 \mathrm{mg} / \mathrm{L}$ and a percentage of effect of $65 \%$ ), with ammonia concentrations greatly above the EC50 value.

For the embryotoxicity test with $P$. lividus, only six samples presented ammonia concentrations below the LOEC value for total ammonia at $\mathrm{pH}$ 8. The toxicity of most samples could be weakly influenced by ammonia, because ammonia concentrations exceeded the LOEC value, but not the EC50 value. For a few samples, the ammonia contribution to toxicity could be considered high, since its concentration exceeded the EC50 value, even if very different elutriate toxicity was found in samples with similar total ammonia concentrations (e.g., DE-w99 and OS-s98).

For the embryo toxicity test with $C$. gigas, most samples had ammonia concentrations below the NOEC value. Only a few samples had ammonia concentrations similar to the NOEC value (TR-w03, SG-s00) or higher (OS-s98, DEw99).

No statistically significant correlation between toxicity and ammonia concentration was found for any bioassay, considering all toxicity data expressed as percentage of effect (correlation coefficients were $0.60,0.42$, and 0.36 for sperm cell and embryo test with $P$. lividus and embryo test with $C$. gigas, respectively; $n=31$ ). The same result was obtained by excluding outliers (percentage of effect $\geqslant$ $90 \%$ ), for which high toxicity is expected not to be attributable just to ammonia presence $(0.04,0.41$, and 0.17 , respectively; $n=28$ ). This suggests that ammonia is less available in some samples due to $\mathrm{pH}$ changes, antagonistic effects with other substances, or organic matter protective effects. There were such small changes in $\mathrm{pH}$ among the elutriate samples (from 7.7 to 8.3 ) that un-ionized ammonia/ammonium dissociation was scarcely influenced. The $\mathrm{pH}$ changes during the execution test were also very small both for sperm cell test (differences included in the range $-0.06,+0.11$ from 0 to $60 \mathrm{~min}$ ) and embryo test $(-0.05,+0.17$ from 0 to $72 \mathrm{~h})$ with $P$. lividus (preliminary tests, unpublished data). Possible antagonistic effects, or organic matter protective effects, could explain the fact that some samples (OS-w99 for sperm cell test, 
Sperm cell toxicity test with $P$. lividus

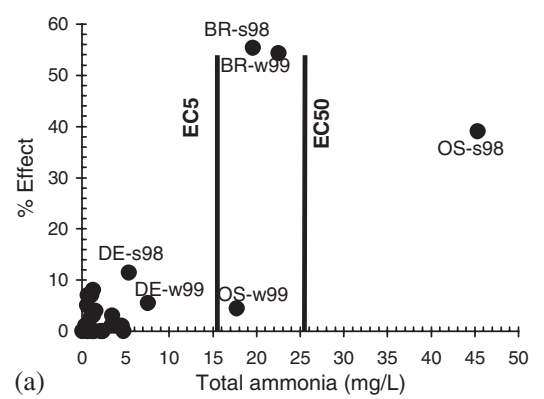

Embryotoxicity test with P. lividus
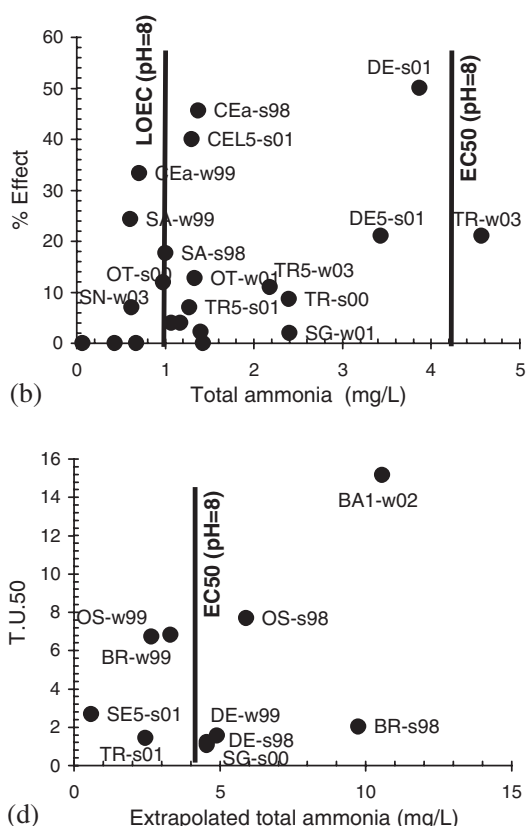

Embryotoxicity test with C. gigas
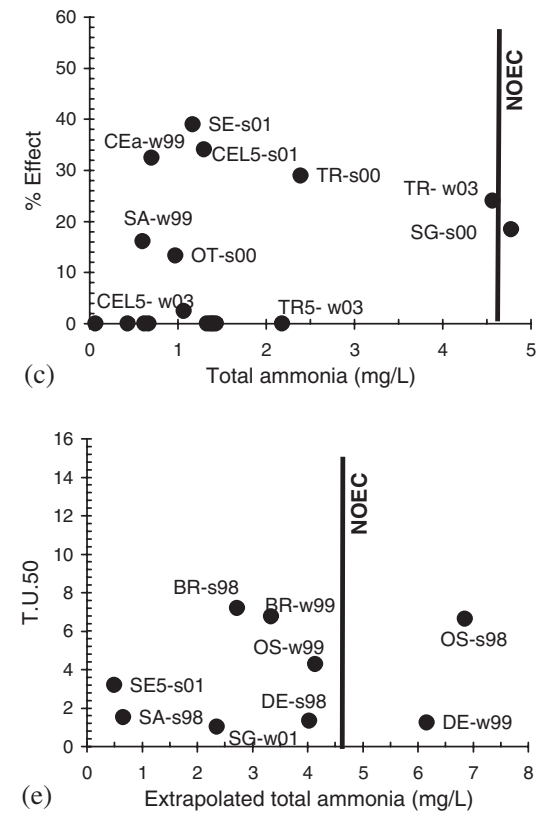

Fig. 2. Total ammonia concentration in elutriates, related to elutriate toxicity (expressed as percentage of effect in samples with low toxicity (a, b, and c) and TU50 ( $\mathrm{d}$ and e) in samples with high toxicity), tested with the sea urchin $P$. lividus and the oyster $C$. gigas. the black bar highlights toxicological parameters for total ammonia (EC5 for sperm cell test and EC50, NOEC, and LOEC for embryotoxicity tests). For samples with high toxicity, total ammonia concentrations were extrapolated for the dilution of samples causing $50 \%$ of effect.

TR-w03 for embryo test with the sea urchin, and SG-s00 for embryo test with the oyster) had high ammonia concentration and low toxicity.

Ammonia concentrations registered in elutriates were generally high. For example, the elutriates deriving from sediments of the estuarine site DE exhibited $5.4 \mathrm{mg} / \mathrm{L}$ (DEs98) and $7.6 \mathrm{mg} / \mathrm{L}$ (DE-w99) of total ammonia in undiluted elutriate. These high values might be explained by large amounts of organic matter, since several fragments of riparian vegetation were found during sample homogenization and high volatile organic matter contents were calculated by loss-on-ignition ( $9 \%$ for DE-s 98 and $7 \%$ for DE-w99). The very high ammonia concentrations in other samples from the industrial area cannot so easily be explained. Total ammonia concentrations of $17.8 \mathrm{mg} / \mathrm{L}$ (OS-w99), $\quad 45.4 \mathrm{mg} / \mathrm{L} \quad$ (OS-s98), $19.6 \mathrm{mg} / \mathrm{L} \quad$ (BR-s98), $22.6 \mathrm{mg} / \mathrm{L}$ (BR-w99), and $160 \mathrm{mg} / \mathrm{L}$ (BA1-w02) cannot be attributed entirely to organic matter. Indeed, most elutriate samples $(70 \%)$ we prepared from Venice lagoon sediments had total ammonia concentrations in the range $0-2.5 \mathrm{mg} / \mathrm{L}$ ( $n=116)$ (Volpi Ghirardini, unpublished data). We assume that industrial discharges could contribute to ammonia content in the sediment and, as a consequence, in the elutriates. In this case ammonia cannot be considered only as a confounding factor, but also as a contaminant.

\section{Conclusion}

This study reports toxicity data on elutriates from sediment of the Venice lagoon, tested with a battery of bioassays using the early life stages of sea urchin and oyster. The possible contributions of sulfide and ammonia to toxicity are discussed, as an evaluation of false positives is an important step in method validation and in particular for evaluating the applicability of methods to a given environment.

The general approach in monitoring programs, suggested by the ISO or OECD standards, for example, is to consider as nonvalid a toxicity test performed on samples with a high concentration of ammonia and sulfide. In a transitional environment, such as a lagoon, where large amounts of organic matter are degraded daily, ammonia and sulfide concentrations could reach toxic thresholds in aqueous matrices. Comparison of the ammonia and sulfide concentrations in the test matrix, test matrix toxicity, and sensitivity limits (NOEC value) of a bioassay for ammonia and sulfide could be a practical approach to performing sensitive bioassays for interpreting toxicity data. For most toxic samples, this means extrapolating ammonia and sulfide concentrations for the dilutions of samples determining the EC50 value.

The results demonstrated that sperm cell and embryo toxicity of elutriates obtained under strong oxidative conditions from sediments of the lagoon of Venice, is not affected by sulfides: two samples exceeded the sensitivity limit for the sperm cell test, but no acute toxicity was found. For ammonia, most elutriate samples tested by the sperm cell test with $P$. lividus and embryotoxicity test with C. gigas had ammonia concentrations below the sensitivity limit of the method. The few samples (from sediments close to the industrial area) exceeding the sensitivity limit of the 
method had such high concentrations of ammonia that a contribution from industrial discharges must be assumed.

As regards the embryotoxicity test with $P$. lividus, most samples had an ammonia concentration between the LOEC and EC50 toxicity thresholds (sample toxicity slightly affected by ammonia) and a few samples exceeded the EC50 toxicity threshold (sample toxicity greatly affected by ammonia).

\section{Acknowledgment}

This work was partly granted by the Consorzio Ricerche Laguna (Co.Ri.La.) of Venice (Italy). Alison Garside revised the English text.

\section{References}

American Society for Testing and Materials (ASTM), 1998. Standard guide for conducting static acute toxicity tests starting with embryos of four species of saltwater bivalve molluscs. E 724-98: ASTM, Philadelphia.

Ankley, G.T., Schubauer-Berigan, M.K., Dierkers, J.R., 1991. Predicting the toxicity of bulk sediments to aquatic organisms with aqueous test fraction: pore water vs. elutriate. Environ. Toxicol. Chem. 10, $1359-1366$.

Arizzi Novelli, A., Argese, E., Tagliapietre, D., Bettiol, C., Volpi Ghirardini, A., 2002. Toxicity of tributyltin and triphenyltin towards early life stages of Paracentrotus lividus (Echinodermata: Echinoidea). Environ. Toxicol. Chem. 21, 859-864.

Arizzi Novelli, A., Losso, C., Ghetti, P.F., Volpi Ghirardini, A., 2003a. Toxicity of heavy metals using sperm cell and embryo toxicity bioassays with Paracentrotus lividus (Echinodermata: Echinoidea): comparisons with exposure concentrations in the Lagoon of Venice (Italy). Environ. Toxicol. Chem. 22, 1295-1301.

Arizzi Novelli, A., Picone, M., Losso, C., Volpi Ghirardini, A., 2003 b. Ammonia as confounding factor in toxicity tests with the sea urchin Paracentrotus lividus (Lmk). Toxicol. Environ. Chem. 85 (4-6), 183-191.

Bay, S., Burgess, R., Nacci, D., 1993. Status and application of Echinoid (Phylum Echinodermata) toxicity test methods. In: Landis, W.G., Hughes, J.S., Lewis, M.A. (Eds.), Environmental Toxicology and Risk Assessment. ASTM STP 1179, Philadelphia, PA, p. 281.

Beiras, R., 2002. Comparison of methods to obtain a liquid phase in marine sediment toxicity bioassays with Paracentrotus lividus sea urchin embryos. Arch. Environ. Contam. Toxicol. 42, 23-28.

Carr, R.S., Chapman, D.C., Howard, C.L., Biedenbach, J.M., 1996 a. Sediment quality triad assessment survey of the Galveston Bay, Texas system. Ecotoxicology 5, 341.

Carr, S.R., Long, E.R., Windom, H.L., Chapman, D.C., Thursby, G., Sloane, G.M., Wolfe, D.A., 1996b. Sediment quality assessment studies of Tampa Bay, Florida. Environ. Toxicol. Chem. 15, $1218-1231$.

Chapman, P.M., Wang, F., 2001. Assessing sediment contamination in estuaries. Environ. Toxicol. Chem. 20, 3-22.

De Witt, T.H., Ditsworth, G.R., Swartz, R.C., 1988. Effects of natural sediment feature on survival of phoxocephalid amphipod Rhepoxynius abronius. Mar. Environ. Res. 25, 99-124.

Finney, D.J., 1971. Probit Analysis. Cambridge Univ. Press, London.

Giesy, J.P., Hoke, R.A., 1990. Freshwater sediment quality criteria: toxicity bioassessment. Sediments chemistry and toxicity of in place pollutants. In: Baudo, G., Muntau (Eds.), Sediments: Chemistry and Toxicity of In-place Pollutants. Lewis, Boca Raton, FL, pp. 255-348.

Greenstein, D.J., Alzadjali, S., Bay, S.M., 1996. Toxicity of ammonia to pacific purple sea urchin (Strongylocentrotus purpuratus) embryos. In:
Allen, M.J., Francisco, C., Hallock, D. (Eds.), Southern California Coastal Water Research Project Annual Report 1995-95, Westminster, CA, pp. $72-77$.

Hamilton, M.A., Russo, R.C., Thurston, R.V., 1978. Trimmed SpearmanKarber method for estimating median lethal concentrations in toxicity bioassays. Environ. Sci. Techn. 12, 714-720.

His, E., Seaman, R.N.L., Beiras, R., 1997. A simplified bivalve larval bioassay method for seawater quality assessment. Water Res. 31, 351-355.

His, E., Beiras, R., Seaman, M., 1999. The assessment of aquatic contamination: bioassays with bivalve larvae. Adv. Marine Biol. 37, $1-178$.

Hooten, R.L., Carr, R.S., 1998. Development of a marine sediment porewater toxicity test using Ulva fasciata zoospores. Enviro. Toxicol. Chem. 17, 932.

Knezovich, J.P., Steichen, D.J., Jelinski, J.A., Anderson, S.L., 1996. Sulfide tolerance of four marine species used to evaluated sediment and pore-water toxicity. Bull. Environ. Contam. Toxicol. 57, 450-457.

Lapota, D., Duckworth, D., Word, J., 2000. Confounding factors in sediment toxicology. Issue Papers: 1-19. Space and Naval Warfare Systems Center San Diego, San Diego, CA, USA.

Losso, C., Arizzi Novelli, A., Picone, M., Volpi Ghirardini, A., Ghetti, P.F., Rudello, D., Ugo, P., 2004a. sulfide as a confounding factor for toxicity bioassays with the sea urchin Paracentrotus lividus: comparison with chemical analysis data. Environ. Toxicol. Chem. 23, 396-401.

Losso, C., Arizzi Novelli, A., Picone, M., Marchetto, D., Pessa, G., Molinaroli, E., Ghetti, P.F., Volpi Ghirardini, A., 2004b. Evaluation of surficial sediment toxicity and sediment physico-chemical characteristics of representative sites in the Lagoon of Venice. J. Mar. Syst. 51, 281-292.

Matthiessen, P., Bifield, S., Jarrett, F., Kirby, M.F., Law, R.J., McMinn, W.R., Sheahan, D.A., Thain, J.E., Whale, G.F., 1998. An assessment of sediment toxicity in the river Tyne estuary, UK, by means of bioassays. Mar. Environ. Res. 45, 1-15.

Morin, J., Morse, J.W., 1999. Ammonium release from suspended sediment in the laguna Madre estuary. Mar. Chem. 65, 97-100.

Postma, J.F., de Valk, S., Dubbeldam, M., Maas, J.L., Tonkes, M., Schipper, C.A., Kater, B.J., 2002. Confounding factors in bioassays with freshwater and marine organisms. Ecotoxicol. Environ. Safet. 53, 226-237.

Reardon, J., Foreman, J.A., Searcy, R.L., 1966. New reactants for the colorimetric 21 determination of ammonia. Clin. Chim. Acta 14 (3), 203-205.

Thursby, G.B., Heltshie, J., Scott, K.J., 1997. Revised approach to test acceptability criteria using a statistical performance assessment. Environ. Toxicol. Chem. 16, 1322-1329.

US Environmental Protection Agency, 1995. Short-Term Methods for Estimating the Chronic Toxicity of Effluents and Receiving Waters to West Coast Marine and Estuarine Organisms. EPA/600/R-95/136, US Environmental Protection Agency. Cincinnati, OH.

Volpi Ghirardini, A., Arizzi Novelli, A., 2001. A sperm cell toxicity test procedure for the Mediterranean species Paracentrotus lividus (Echinodermata: Echinoidea). Environ. Technol. 22, 439-445.

Volpi Ghirardini, A., Arizzi Novelli, A., Losso, C., Ghetti, P.F., 2003. Sea urchin toxicity bioassays for sediment quality assessment in the Lagoon of Venice (Italy). Chem. Ecol. 19 (2-3), 99-111.

Volpi Ghirardini, A., Arizzi Novelli, A., Tagliapietra, D., 2005. Sediment toxicity assessment in the Lagoon of Venice (Italy) using Paracentrotus lividus (Echinodermata: Echinoidea) fertilization and embryo bioassays. Environ. Int. 31, 1065-1077.

Wang, F., Chapman, P.M., 1999. Biological implications of sulfide in sediment - a review focusing on sediment toxicity. Environ. Toxicol. Chem. 18, 2526-2532.

Whiteman, F.W., Ankley, G.T., Kahl, M.D., Rau, D.M., Balcer, M.D., 1996. Evaluation of interstitial water as a route of exposure for ammonia in sediment tests with benthic macroinvertebrates. Environ. Toxicol. Chem. 15, 794-801. 